\title{
New Opportunities for the Tourism Market: Senior Tourism and Accessible Tourism
}

\author{
Elisa Alén, Trinidad Domínguez and Nieves Losada \\ University of Vigo, \\ Spain
}

\section{Introduction}

When speaking of trends, people tend to relatives arguments due to their fragile demonstrability. To prepare this chapter, we began with two objectives: first, to analyse trends in the tourism sector and their evolution, and secondly, in juxtaposition, to examine tourism trends from a socio-demographic perspective. Our goal is to deepen our understanding of two types of tourism that are both future trends in the tourism sector, namely, senior tourism and accessible tourism. This paper does not seek to review market niches or narrow market segments, but rather the opening of new tourism segments based on the synergies that can be generated between these segments based on both the potential and real needs of tourists. Accessibility is established as the key link, as older people and people with temporarily or permanently restricted capacities are the direct beneficiaries of accessibility. Indeed, accessibility is considered to be a parameter of quality and usability for tourist attractions and is, therefore, a key determinant of user satisfaction and loyalty. Also, we must not forget that disability is often directly related to the elderly and that, "with increasing age, disability or restricted capacities also increase in a gradual way" (Burnett, 1996:7).

Although these segments of tourism have not been very important in the past, their importance is now growing and they have been established as priorities in policy lines of action. For instance, in 2009, the European Commission launched the Calypso 27 project (aligned with the objectives of social tourism), arguing that by increasing the accessibility of disadvantaged populations to tourism, social tourism contributes to achieving the key objectives of the Lisbon Strategy, particularly in terms of economic development and employment. This project has four target groups: senior citizens and retirees, youths, the disabled and families with difficulties (e.g., social, financial). It intends "to correct social inequalities among the population, as these exclude many from tourism and travel, and ensure universal access to vacations, while aiming to generate economic activity and growth in Europe, combat seasonality in tourism, create more and better jobs in the tourism sector and strengthen the ties among European citizens."

Borja et al. (2002) have shown that the segment of adults over 55 years of age will increase the overall volume of tourism the most; these adults are characterised by extensive experience in tourism, making them more demanding consumers and allowing demand to shift away from peak seasons because this is a segment of the population that is often retired. This segment is augmented by disabled people, with whom senior citizens share 
common needs, mainly accessibility. Thus, this potential segment of tourists approaches one fifth of the population. Accessibility improvements not only benefit these groups but also pregnant women and those with temporarily restricted capacities, such as children and families. In general, everyone benefits from greater accessibility.

The aim of this study was to determine the profile and behaviour of the elderly traveller and that of those seeking accessible tourism, as well as the market opportunities and profitability that can be generated nationally and at the European level, as it was assumed that these two types of tourists require similar amenities. Initially, we reviewed the existing literature to define and identify those variables that influence or explain tourists' motivations. Subsequently, we carried out a quantitative study in which data were collected from potential tourists. After analysing this data, we concluded that the elderly and tourists concerned with accessibility create a market of significant size both from demographic and economic perspectives and those active policies should be implemented to provide tourist attractions that can be enjoyed by all travellers, on the basis of both quality and social responsibility.

\section{New market trends}

\subsection{Trends in the tourism sector}

According to the World Tourism Organisation (WTO), some of the 2020 future market trends are: an increase in the number of elderly tourists, a change from active vacations to experience-based holidays and an ever increasingly complex segmentation of the demand to comply with the different objectives or purposes of traditional travel (e.g., travel to destinations, honeymoons with sun and beach access, or cultural or cruise-related products).

Therefore, we can say that, in general, the current trends in tourism demand are conditioned primarily by the following scenarios:

- The increasing importance, within the overall demand, of the segment of tourists over 55 years of age.

- Higher demand in terms of quality and sophistication.

- More segmented markets.

- A shortage of time and plenty of money.

- A growing awareness of environmental and sustainability issues.

- More participatory and active holidays, with longer itineraries and itineraries that are managed individually in many cases.

\subsection{Socio-demographic trends of tourists}

Studying the evolution of society as a whole makes it easy to set future trends in tourism demand because it also requires the study of the elements linked to individuals' economic situations, both from social and economic perspectives as well as a behavioural perspective.

Two blocks of study were structured for this purpose: population and family structure, and habits of behaviour and leisure. For this analysis, Europe was used as a reference, as it is the continent with the largest number of inbound tourists received both now and in the shortterm future. 


\subsubsection{Population and family structure: Current situation and trends / forecasts}

In Europe, there are already more elderly people (over 65 years old) than children. In 2004, the elderly population (75.4 million) exceeded the younger population (less than 14 years of age) (74 million). This finding follows the trend of the decrease in the latter from 1984 onwards in favour of a greater number of people older than 65 years of age, who now represent one-sixth of the European population (Institute for Family Policy-IPF-2007). When we add the significant decrease in mortality and fertility to this, we observe a remarkable transformation of the population pyramid, setting the European stage for a situation in 2025 in which the maximum width of the pyramid will be comprised of the group between 40 and 60 years old, thus causing the pyramid to rupture.

One cannot forget either that family structure has changed, with a reduction in the average household size to 2.4 members in the EU 15 (2000) and the emergence of single-parent families who tend to invest income increases not in having more children but, increasingly, in the already existing family.

\subsubsection{Habits and leisure behaviour: Current status and trends / forecasts}

Clearly, the behavioural habits of tourists are heavily influenced by their socio-demographic contexts, i.e., education level, age, economic activity, environment and lifestyle, with the largest percentage of tourists who travel being those with a higher level of education and employment positions that include greater responsibilities and salaries.

Tourism is also a seasonal activity, occurring mainly during holiday periods: summer, Easter and Christmas, as well as weekends. The primary reasons for tourism are leisure travel and vacations, followed by visits to relatives and friends and, to a lesser degree, work or business and studies. The duration of trips has tended to decrease and ranges from one week to two weeks. Note that short trips abound among young people, while the trip duration increases for adults over the age of 40 .

We can say, therefore, that the tourism industry needs to adapt its offerings to these new trends and demographic behaviours, which are mainly characterised by:

- More holiday periods.

- Shorter vacations.

- Combining leisure travel / leisure and work.

- Searching for products that offer more enriching experiences in a shorter period of time.

- Discretionary tourism as an escape for rest, relaxation and leisure.

\section{Senior tourism and accessible tourism - Theoretical bases}

One of the key elements that can be drawn from the above, both from the perspective of the tourist sector as well as the individual tourist, is the importance of the segment formed by older people that, because of the aging population, will continue to increase steadily. Thus, it is essential to consider senior tourism as crucial to the reformulation of tourism or the range of available products and destinations. In addition, senior tourism is directly linked to accessible tourism because disability is often directly related to the elderly. According to the World Health Organisation (WHO), 35\% of people over 65 have some type of disability (Fuguet, 2008). 
These two types of tourism must adapt and meet the expectations of the new scenario proposed above. At the sector level, great importance is given to the segment of the population over 55 years of age, but not as a niche market, rather as an integrated part of tourism offerings based on elements of quality and environmental sustainability. They are not subject to established periods of enjoyment, but can be variable depending on the user. The characteristics of the product offered can be adapted to different formats and seasonal holiday periods and to very different motivations: leisure, relaxation, pleasure or simply experiences according to the behaviour of the tourist.

Below, a theoretical contextualisation is presented for both types of tourists to outline their main characteristics and their fundamental bases.

\subsection{Senior tourism}

Senior tourism is a segment that has not held great importance in the tourism industry, although this trend is changing. The importance of the senior citizen segment in markets, in general, is determined by the process of aging (Norman et al., 2001:115; Szmigin and Carrigan, 2001:1092), which is linked to improvements in the economic status and the health conditions of this group (Gunter, 1998:6). In this sense, some authors suggest that the unprecedented change in the demographic structure of the population will entail a shift in markets (Nedelea and State, 2008). Specifically, these authors point to the baby boomer generation as one that will introduce profound changes in the compositions of markets in the coming decades (Prideaux et al., 2001:211; Ramos, 2005:406). We must remember that the most important factors for an aging population are its increasing life expectancy, lower birth rate and the impact that the baby boomer generation will have on the rest of the population as it ages (Metz and Underwood, 2005:5). Thus, because the baby boomer generation has begun to form part of the mature population, an increase in attention to seniors as consumers has resulted (Norman et al., 2001:114). Several years ago, Tongren (1988:138) echoed the importance of this generation and pointed to the desirability of not limiting ourselves to the characteristics of the elderly consumer today, but also to study the buying behaviour of this generation with regard to the products and services they will demand in the near future.

This tourist segment is still considered very new; therefore, there is not much literature that addresses their issues. This leads to a dearth of a description of the concept, as there is no clear definition of it or agreement by authors (Chen, 2009; Le Serre, 2008). This lack of consensus highlights its fragility and its impact on two key issues: from a theoretical view, the lack of a conceptual framework to research the behaviour of the elderly, and from an applied perspective, the lack of suitable tools to identify the senior consumer (Le Serre, 2008). This phenomenon is clearly reflected when analysing the literature. Thus, Hossain, Bailey and Lubulwa (2003: 4) use the term "senior" for those 55 years of age or older, and non-seniors are those under 55 but over 15 years of age. In turn, these authors segment seniors into two subgroups: younger seniors, from 55 to 64 years old and older seniors, 65 and older. On the other hand, Alcaide (2005) states that some companies set the senior age break at 55 years of age, the age at which the consumer begins to sense different needs and forecast and plan for aging. From this age, they are considered as part of the segment of the elderly in the banking system, which begins to differentiate between and specialise treatment for them. Other companies set the boundary at 60, the age that marks the 
differentiation between older people and the mature, and begin to consider the possibilities of offerings that are appropriate to the interests and realities of this group. According to García and Martorell (2007), senior citizen tourists are those over 65 years of age. In the Diagnostic Phase of the Plan for Enhancing the Competitiveness (PRC) of the Tourism Cluster in Montevideo (2009), senior citizen tourism is considered to be comprised of groups made up of people over 60 who are mentally and physically self-sufficient and have the time and financial resources to travel and visit a tourist destination. In sum, it may be noted that the ages used to identify senior citizen tourists vary, and we can find four groups of studies:

- $\quad$ Those that define a senior citizen as an individual over 50 years of age (Cleaver, 2000; Kim, Wei and Ruys, 2003; Littrell, Paige and Song, 2004; Sellick, 2004; Wang, 2006).

- Those that place the senior tourist beyond the age of 55 (Fleischer and Pizam, 2002; Hossain, Bailey and Lubulwa, 2003, Hsu and Lee, 2002; Huang and Tsai, 2003; Reece, 2004; Shim, Gehrt and Siek, 2005).

- $\quad$ Those that define the senior tourist as 60 years of age or older (Horneman, Carter, Wey and Ruys, 2002; Jang and Wu, 2006; Lee and Tideswell, 2005).

- Those that define the senior citizen tourist as between the ages 65 and 74 (Zimmer, Brayley, and Searle, 1995).

Therefore, the issue of the use of cognitive age - whether subjective or self-perceived - to assess the buying behaviour of the older consumer as an alternative to chronological age arises (Barak and Schiffman, 1981; González et al., 2009; Patterson, 2006; Wilkes, 1992). Grande (1993:56) asserts that "the key age for segmenting the market is the selfperceived age, which is what sets the lifestyle by determining attitudes, interests and opinions." Similarly, Gwinner and Stephens (in Iyer et al., 2008) have shown that cognitive age may explain some consumer behaviours better than other commonly used variables such as income, education and health.

The lack of consensus suggests an inconsistency in the concept. Le Serre (2008) proposes a new definition based on a review of the available literature on tourism and marketing magazines. He claims that the concept of the senior consumer is characterised by two types of elements: a) those that do not vary, regardless of marketing specialty and of the type of industry in which s/he works; all researchers agree with these intrinsic characteristics of the senior consumer and b) variable elements. The elements that do not change when considering the concept of senior consumers are:

- Senior citizen consumers are an important potential market for the industry because of the large number of older people and their purchasing power;

- They have reached or passed the threshold of the age at which there are some signs of aging. This element is linked to the etymological meaning of the word; originally, 'senior' meant older;

- They feel young relative to their chronological age and, as a consequence, there is a new subjective variable related to the self-perception of a person and his or her feelings about particular age groups. This variable has already been used to segment the senior market, and previous results confirm that it is more useful than chronological age to explain the purchasing behaviour of this group (Le Serre, 2008).

With respect to aspects that vary in the definition of the senior consumer, a review of the literature highlights two issues: 1). each definition is intrinsically linked to an approach that 
allows a differentiation between senior and non-senior consumers, and 2). there is a lack of consensus on the definition of a senior consumer and, consequently, the criteria used to define him or her.

In marketing, two criteria are used: chronological age and retirement. With regard to chronological age, there was a lack of agreement about the age of the onset of the senior segment. Some authors justify why they choose a certain age, but others do not. Even the justifications themselves may differ from each other. These discrepancies make it difficult to compare the results obtained by different studies. In addition, chronological age is a very simple criterion in regards to defining the entire senior segment, which is a very heterogeneous group. Finally, we should also note that there is a dynamic approach linked to historical and cultural circumstances (e.g., medical advances); hence, the economic and social realities can vary over time. Consequently, chronological age is a criterion that must be supplemented. On the other hand, the criterion "retirement" can also create difficulties in comparing results because it changes from one country to another. Although in many countries the legal age of retirement is age 65, this age distinction differs in other countries. For example, in Norway the legal age of retirement is 67, and in Korea and France the legal age of retirement is 60 (Le Serre, 2008). Moreover, under certain circumstances, people may qualify or apply for early retirement or enjoy a pre-retirement. The legal age of retirement may also vary depending on social and political changes. These observations emphasise the cultural dimension of the concept of a senior and suggest that the retirement criterion is too restrictive and the scientific community should supplement it.

There is, therefore, confusion about the definition of tourism activities undertaken by older people derived from the multiplicity of meanings offered by the concept of "older or senior." However, in light of the discussion above, it can be taken as a hypothesis that senior tourism covers a broad spectrum of activities that are done by older people, retired or not retired, 55 years or more, with different income levels. In this sense, it seems logical to consider that senior tourism should not be treated simply as a non-seasonal type of active aging and directed to a minority group, but as a much more extensive activity.

\subsection{Accessible tourism}

When talking about tourism for people with disabilities, or limited or restricted capacities, one of the biggest problems is the great variety of existing words to convey very similar ideas. "These euphemisms have the effect of depoliticising our own terminology and devaluing one's own vision of ourselves as people with disabilities" (Heumann, 1993:262), sometimes reaching the point of distorting and limiting the meaning, as in the case of the term "accessibility", or simply creating confusion. "The choice of language and labels that emerge from within the disability community creates positive imagery to counter this derogatory and oppressive language used by those outside the culture of disability to describe people with disabilities" (Gilson and Depoy, 2000: 211). An example of this is the variety of terms relating to leisure and recreation by people with partly or wholly restricted capacities.

On September 27, 1980, in Manila (Philippines), the terms tourism and accessibility were first linked by the Manila Declaration, and later elaborated upon by the World Tourism Organisation. This declaration recognised tourism as a fundamental right and key vehicle 
for human development. It recommended the regulation of tourist services to member states, highlighting the most important aspects of tourist accessibility. Pérez and González (2003), note that accessible tourism has been conceived from its inception as one that guarantees the use and enjoyment of tourism by people with physical, mental or sensory impairment disabilities, i.e., to facilitate the access of people with disabilities to infrastructure and tourism services. According to Gómez (2002), accessible tourism can be defined as the variety of activities occurring during the free time devoted to tourism by people with restricted capacities, which enables them to fully integrate their functional and psychological perspectives and achieve individual satisfaction and social development. It follows that an accessible activity is synonymous with integration.

In the late 1980s, another term arose to refer to tourism for people with restricted capacities, that is, tourism for all, which can be defined as the set of activities oriented towards tourism and leisure that take place in an individual's free time and that all people can access, regardless of varying degrees of ability / disability, achieving full integration and, therefore, an individual and social fulfilment from the interaction of the user with the environment. Its objective is, "to achieve the normalisation of tourism and leisure for all people and contributing to their incorporation as users of tourism infrastructure and services" (Fernández-Villarán, 2007:49). One tries to design tourism for all, i.e., activities that can be enjoyed by individuals without any disability as well as by different groups with specific accessibility needs (physical, mental or sensory) without any differentiation or discrimination among them.

There is also the concept of accessible tourism for all. Almost identical to tourism for all, this concept "is not based on the separate creation of services for people with disabilities, but aims at the full integration and inclusion of people with special needs, particularly disabled people and elderly people, in the tourism sector" (Leidner, 2006:1). That is, all tourists can be active participants in the tourism sector, regardless of their characteristics, abilities and needs.

Other concepts that are also employed in the field of tourism in relation to those with disabilities (although to a lesser degree and with limited significance) are social tourism and quality tourism. "Social tourism was created with the objective of making leisure tourism available to a broad segment of the population. All authors agree that, "it is a modality that seeks to promote leisure and conviviality among these disadvantaged groups" (FernándezVillarán, 2007: 50). This idea is based on providing resources to those groups with limited resources - elderly, young people or people with different abilities - in order allow them to travel with the appropriate conditions of economy, accessibility, safety and comfort.

In relation to quality tourism, it is essential to define the term quality to understand the extent to which it can be applied to tourism based on the disabled user. Quality can be defined from multiple perspectives. One of the most interesting perspectives comes from the discernment of value, defined as a property or a set of properties inherent to a product or service that permits it to be appreciated equally, better or worse than others like it. Meeting the needs and expectations of consumers of products / services is the key to quality, which should not be perceived as a luxury or privilege, but as a tool to differentiate the positioning to competitors. "We will be placed sooner rather than later in a scenario where terms such as: accessible, barrier-free, universal, for all, etc. will stop being used and talk only of quality 
tourism, that is, offering a comprehensive service appropriate to each type of client regardless of their particular conditions" (Salgado, 2007:1).

Given the heterogeneity of this group and its broad classification according to the International Classification of Functioning, Disability and Health (ICF) (WHO, 2001), a number of subdivisions marked by common characteristics among them in which disabled people are included were established:

- Physical or motor: due to neurological, muscular, surgical or traumatic causes.

- Mobility: occurs when there is difficulty in maintaining and changing the different positions of the body as well as standing up, lying down, standing, sitting or moving. Those movements involving the use or transportation of various mobility aids and objects are also included.

- Apprehension: sometimes with a considerable amount of stress or anxiety, the person may provoke in him / herself a response that in itself is harmful to the body, creating psychological situations that lead to physical or trauma problems.

- Psychic: those arising from problems in intellectual abilities or conditions therein.

- Mental illness: disorders related to different degrees of mental disability.

- Intellectual disability: resulting from difficulty recognising people, objects, orientation in space and time, recalling past events or understanding and executing simple or complex orders.

- Sensory: those arising from injuries causing a decrease in or loss of a sense.

- Visual: the individual may find it difficult to perceive any image, carry out visual tasks wholly or in detail, or other disabilities related to vision.

- Hearing: the person may have trouble hearing any sound, hearing loud sounds or hearing speech.

- Communication or speech: problems that arise when trying to communicate through speech, alternative languages, unsigned gestures or by conventional reading and writing.

- Hidden: those that are not visible to the naked eye. We distinguish mainly:

- Visceral: those caused by cardiovascular insufficiency and / or respiratory or kidney dysfunction or problems including enterostomies.

- Pathological: caused by allergies, epilepsy, haemophilia, dwarfism, gigantism, leprosy or similar conditions.

- Multiple disabilities: when an individual has more than one disability simultaneously, such as deaf-mutes.

\section{Potential and actual market analysis}

\subsection{Market opportunity}

Both economic and social yields set market trends from the point of view of supply. One works with what is demanded by the consumer or what is assumed as a market opportunity for one's area of competence. Working with accessibility in the tourism sector results in a number of advantages that can be converted into opportunities that are reflected both in the senior segment of tourists as well as tourists who are disabled or have temporarily restricted capacities. Some of the more important are: 
Business opportunity: with senior tourism and accessible tourism, a competitive advantage is generated. This is not a niche market, but an extension of the tourist segment based on quality as it increases the supply of goods and services.

Growing market segment through demographic and lifestyle changes: there is a growing segment of people with disabilities or with restricted capacities and socio-demographic and lifestyle changes anticipate continued growth, mainly driven by: work or traffic accidents, population aging, war, changes in the number of people with disabilities or possible variations in the segment of people affected by diseases with consequences that undermine capacities (hidden disabilities such as leukaemia, cancer, etc.).

Increased market: as shown in Tables 1 and 2, the percentage of the market related to people with disabilities and older people, i.e., the direct beneficiaries of accessibility, is very attractive, representing around one fifth of the global population between the two groups.

Shifting away from seasonality: one of the big problems with the tourism sector in Spain and in countries with similar tourism models is seasonality, i.e., the mass influx of tourists during predetermined periods. Senior and accessible tourism would help to move away from seasonality, as most disabled people do not work. According to Eurostat data, $51 \%$ of this segment is not active and receive a disability pension or retirement (Eurostat, 2005). This represents a very attractive market, both due to its size and their availability to travel. A similar case is found with the elderly, who are no longer integrated into the labour market and have occasion and money to enjoy their leisure time. Also, one should not ignore the increase in both state and European initiatives regarding travel programmes for senior citizens and persons with disabilities, which are offered primarily in low-intensity tourism periods. Spain has been a pioneer in its conception of senior tourism as a reality independent of other tourism subsectors (Álvarez, 2006) and has even served as a model for other countries with its IMSERSO (Institute for the Elderly and Social Services) programmes, which attempt to improve the quality of life of older people by increasing their participation in travel and tourism activities, while contributing to the creation or maintenance of employment in the tourism sector in the low season.

Competitive and quality tourism: there are many countries - mainly the Nordic countries, Germany and the United Kingdom - where accessibility is even more evolved. They encourage their citizens to view travel as an activity of daily life and a method of personal fulfilment. Spain is one of the most popular destinations and, thus, should tend towards a quality image. To do this, it is necessary to raise awareness of the quality tourism sector, with the implementation of different standards, such as UNE 17001-2, which certifies the management of systems for restricted accessibility.

Social rights for all: in 1996, the EU set into motion the first steps that require all states to recognise the rights of persons with disabilities, assuming that the needs of all people are equally important, respecting human diversity as a base for building society and the provisioning of resources to ensure equal opportunities for all citizens to participate in social life.

\subsection{Demand figures}

When one speaks of data regarding people with disabilities, the numbers can vary greatly depending on the source (see Table 1). This fact arises from the commentary above, i.e., the variation in terms of definitions and criteria applied to the term disability. 


\begin{tabular}{|c|c|c|c|}
\hline \multicolumn{4}{|c|}{ POTENTIAL OR OVERALL DEMAND FOR PEOPLE WITH DISABILITIES } \\
\hline Location & Estimate & $\begin{array}{c}\% \text { of the } \\
\text { population }\end{array}$ & Source or Reference \\
\hline Global & $\begin{array}{l}\text { From } 600 \text { to } 859 \text { million } \\
\text { people. }\end{array}$ & From $9 \%$ to $13 \%$ & $\begin{array}{ll}\text { - } & \text { Van Horn, } 2002 . \\
\text { - } & \text { Horgan-Jones and } \\
& \text { Ringaert, } 2004 .\end{array}$ \\
\hline \multirow{2}{*}{ USA } & Almost 54 million people. & $21 \%$ & $\begin{array}{l}\text { U.S. Department of } \\
\text { Commerce, } 1997 .\end{array}$ \\
\hline & $\begin{array}{l}\text { From } 50 \text { to } 80 \text { million } \\
\text { people. }\end{array}$ & $\begin{array}{l}\text { From } 16 \% \text { to } \\
26 \%\end{array}$ & - $\quad$ Stumbo and Pegg, 2005. \\
\hline Canada & $\begin{array}{l}\text { More than } 2.7 \text { million people } \\
\text { in } 1991 .\end{array}$ & $15.5 \%$ & Van Horn, 2002. \\
\hline Australia & $\begin{array}{l}\text { More than } 3 \text { million people } \\
\text { in } 1993 .\end{array}$ & $18 \%$ & - $\quad$ Darcy, 1998. \\
\hline \multirow{6}{*}{ Europe } & $\begin{array}{l}\text { Around } 45 \text { million people in } \\
\text { the EU-25 countries (aged } 16 \\
\text { to } 64 \text { years) }\end{array}$ & $15.7 \%$ & $\begin{array}{l}\text { - Dupré and Karjalainen, } \\
\text { Eurostat publication } \\
\text { (2003). }\end{array}$ \\
\hline & $\begin{array}{l}\text { From } 45 \text { to } 90 \text { million people } \\
\text { who have some type of } \\
\text { disability }\end{array}$ & $\begin{array}{l}\text { From } 10 \% \text { to } \\
20 \%\end{array}$ & $\begin{array}{l}\text { - } \quad \text { Toerisme Vlaanderen } \\
\text { (2001). } \\
\text { National Disability } \\
\text { Authority (2003). }\end{array}$ \\
\hline & $\begin{array}{l}50 \text { million people in } \\
\text { extended Europe. }\end{array}$ & Aprox. 11\% & $\begin{array}{ll}\text { - } & \text { European Disability } \\
\text { - } & \text { Forum, } 2005 . \\
\text { - } & \text { Gerlin, } 2005 . \\
\text { - } & \text { Qualitas, 2004. } \\
\text { - } & \text { Brown, 1991. } \\
\text { - } & \text { Horgan Horn, 2002. } \\
& \text { Ringaert, 2004. }\end{array}$ \\
\hline & $\begin{array}{l}\text { From } 69 \text { to } 92 \text { million } \\
\text { people. }\end{array}$ & $\begin{array}{l}\text { From } 15 \% \text { to } \\
20 \%\end{array}$ & - $\quad$ Pühretmair, 2004. \\
\hline & $\begin{array}{l}\text { From } 60 \text { to } 80 \text { million } \\
\text { disabled and reduced } \\
\text { mobility people. }\end{array}$ & $\begin{array}{l}\text { From } 13 \% \text { to } \\
17 \%\end{array}$ & $\begin{array}{l}\text { - } \quad \text { Community Research and } \\
\text { Development Information } \\
\text { Service CORDIS, } 1995 .\end{array}$ \\
\hline & $\begin{array}{l}\text { From } 92 \text { to } 115 \text { million } \\
\text { people. }\end{array}$ & $\begin{array}{l}\text { From } 20 \% \text { to } \\
25 \%\end{array}$ & - $\quad$ Stumbo and Pegg, 2005. \\
\hline
\end{tabular}

Table 1. People with disabilities. Overall demand. 
If we now analyse the figures for older people's overall demand (see Table 2), we see that, at the European level, there are older people than children. Furthermore, in 2004, the population over 65 years of age (75.4 million) exceeded that of the population aged 14 years or under (74 million). This continues the trend since 1984 for the decrease in the latter in favour of people over 65, who now account for one sixth of the European population (IPF, 2007). Focusing on Spain, only one in seven Spaniards is young and only $14.5 \%$ of the population is under 14, while one out of every six Spaniards is over 65. Spain is one of the notable leaders in the rankings of aging populations. This demographic transition is also reinforced by the low birth rate. By 2020, it is estimated that $20 \%$ of the population will be over 64 years of age (IPF, 2006). Spain will be one of those countries that experiences a significant demographic aging in Europe, and one in two people will be at least 55 years of age in 2050.

\begin{tabular}{|c|c|c|c|}
\hline Location & Estimate & $\%$ of the population & Source or Reference \\
\hline Global & $\begin{array}{l}\text { About } 600 \text { million } \\
\text { people (in } 2025 \text { it is } \\
\text { estimated that it will be } \\
1.6 \text { billion people) }\end{array}$ & $10 \%$ & - $\quad$ OMS, 2000 \\
\hline USA & $\begin{array}{l}\text { About } 31.88 \text { million } \\
\text { people }\end{array}$ & $12.4 \%$ & $\begin{array}{ll}\text { - } & \text { U.S. Department of } \\
\text { Commerce, } 1997\end{array}$ \\
\hline Europe & $\begin{array}{l}\text { More than } 85 \text { million } \\
\text { people }\end{array}$ & $16.6 \%$ & - $\quad$ IPF, 2009 \\
\hline Spain & $\begin{array}{l}\text { More than } 6.5 \text { million } \\
\text { people }\end{array}$ & $16.8 \%$ & $\begin{array}{ll} & \text { INE (National } \\
\text { Institute of } \\
\text { Statistics), } 2008\end{array}$ \\
\hline
\end{tabular}

Table 2. Senior citizens

Elderly people, aged 65 years or older without disabilities, comprise $10.9 \%$ of the total Spanish population, due to the aging population. Focusing on this segment, we observe that "travel and tourism," which is the second activity they would like to do after "walking", is a desire shared by $60 \%$ of women and $46 \%$ of men (NSI, 1995).

When determining the number of potential tourists who directly benefit from accessibility, we found different sources with different estimates. The potential market for accessibility has been currently estimated at 127.5 million beneficiaries in Europe; this figure includes 7 segments (Buhalis et al., 2005):

- People with mobility impairments.

- People with visual impairments.

- People with hearing impairments.

- People with speech impairments.

- People with mental or intellectual disabilities.

- People with hidden disabilities.

- $\quad$ Senior citizens.

When we perform a more detailed study of the segment of the population benefiting from the removal of accessibility barriers in Spain (see Table 3), the figure totals 16 million people, thus representing almost $40 \%$ of the Spanish population (Ministry of Labour and Social Affairs, 2003:28). 


\begin{tabular}{|c|c|c|c|}
\hline Beneficiaries of accessibility & Estimate & $\begin{array}{c}\text { \% of the } \\
\text { population }\end{array}$ & Source or reference \\
\hline People with disabilities & $3,528,221$ & $8.8 \%$ & INE - EDDES, 1999. \\
\hline People older than 64 years of age & $6,434,609$ & $16 \%$ & INE - EDDES, 1999. \\
\hline No disability & $4,361,957$ & $10.9 \%$ & INE - EDDES, 1999. \\
\hline People without disabilities ${ }^{1}$ & $7,828,635$ & $19.5 \%$ & INE-EPA, 1999a. \\
\hline Pregnant women ${ }^{2}$ & 209,475 & $0.5 \%$ & INE - EMH, 1997. \\
\hline Temporarily disabled people & 515,140 & $1.3 \%$ & INE- EMH, 1997. \\
\hline Total affected by barriers & $15,718,813$ & $39.1 \%$ & \\
\hline Total Spanish population & $40,202,160$ & $100 \%$ & INE - EDDES, 1999. \\
\hline
\end{tabular}

${ }^{1}$ A member is considered to be a person younger than 65 for each family unit, forming part of the collective of beneficiaries from the removal of accessibility barriers due to transitory circumstances.

${ }^{2}$ Includes people affected by fractures, trauma, sprains and injuries to ligaments and bones.

Sources: National Statistical Institute, documents from the Survey on Disabilities, Impairments and Health Status (EDDES), Labour Force Survey (LFS), Hospital Morbidity Survey (EMH) and Accessibility White Paper (Ministry of Labour and Social Affairs, 2002 and 2003).

Table 3. Beneficiaries of the removal of accessibility barriers in Spain

Based on the data, people with disabilities and older people, i.e., the direct beneficiaries of accessibility represent almost a fifth of the world population, totalling between 1.3 and 1.6 billion. In Europe and the United States, the figures are larger, encompassing more than a quarter of the population. Moreover, there is an increasing number of consumers with disabilities and older people who demand goods and tourist services, who together with families with children have increased their number of trips. These three groups have similar needs for accessible tourism (Rains, 2008). According to the European Commission (1996), the approximate figures total 35 million potential overnight travellers and 630 million overnight stays each year (see Table 4). However, as the document itself points out, not everyone is able to experience tourism. In some cases, their disabilities prevent them from travelling and, in others; their economic conditions prevent them from doing so. In contrast, there are other groups that would benefit from accessibility, such as pregnant women, people with transitory physical disabilities, people with temporarily reduced mobility or communication, or families with children, as discussed above.

\begin{tabular}{|c|c|c|}
\hline \multicolumn{3}{|c|}{ OVERALL DEMAND } \\
\hline \multirow{2}{*}{ Europe } & $\begin{array}{l}\text { - } 8 \text { million who will travel abroad. } \\
\text { - } \quad 15 \text { million who will travel } \\
\text { domestically. } \\
\text { - } \quad 22 \text { million local day trips. } \\
\text { - } \quad \text { Average of } 0.5 \text { companions. }\end{array}$ & \multirow{2}{*}{$\begin{array}{l}\text { - } \quad \text { European Commission DG } \\
\text { XIII “Tourism” unit, } 1996 .\end{array}$} \\
\hline & $\begin{array}{l}\text { This would comprise a potential market } \\
\text { of } 35 \text { million travellers who stay } \\
\text { overnight and } 630 \text { million hotel nights } \\
\text { annually. }\end{array}$ & \\
\hline
\end{tabular}

Table 4. Overall demand of European tourists with disabilities

The WTO estimates that by 2050, the population aged 60 and over will make more than 2 billion international trips as compared to 593 million in 1999 (Patterson, 2006:214). In Spain, 
$75 \%$ of couples without children in which the head of the family is between 51-64 years of age made some kind of trip last year (ITS, 2010) and thus comprise the third most travelled group as compared with the rest of the Spanish population.

\section{Profile and behaviour}

To study the profile and behaviour of the segments of tourists with disabilities and senior tourists, we have chosen to conduct the analyses separately (despite their similar needs) in order to establish their behaviours more clearly and concisely.

\subsection{Disabled tourists}

The literature on the segmentation of tourists with disabilities in Europe is scarce; above all, there is mostly public institutional and organisational research, for which a clear statistical methodology was generally applied.

Here, we examine two of the most relevant studies. The first is the Federal Ministry of Economics and Technology of Germany (2004), which conducted a survey of German tourists with disabilities, highlighting the following main conclusions:

- $\quad$ More than half of respondents were over 65 years of age.

- Savings and pensions were the primary means of subsistence.

- $\quad$ The average income was $€ 2,250$ / month.

- Over $50 \%$ of respondents had a degree of disability approaching $100 \%$.

- The largest group was people with physical disabilities, representing more than $60 \%$.

- People with disabilities travel less compared to people without disabilities.

- $\quad 37 \%$ of respondents had decided not to travel due to lack of accessible facilities.

- $\quad 48 \%$ of respondents would travel more frequently if more accessible services were available.

The other study is the National Agency for New Technologies, Energy and Environment of Italy (ENEA) (1999). The primary conclusions are summarised below:

- $\quad 54 \%$ of respondents were women and $46 \%$ were men.

- The respondents mainly belonged to the middle class (i.e., clerks, teachers, small business owners).

- Their trips were usually self-organised; $79 \%$ of the time, the respondents organised their own trips. The rest of the time, the respondents relied on travel agents, tour operators and / or associations and support agencies.

To analyse the segment of Spanish tourists with disabilities, we began with the premise that people with disabilities form a group of users with the widest range of needs and, therefore, requirements. The identification of their profile and behaviour was conducted through quantitative research. Thus, for data collection, a quota sampling was used, dividing the population into distinct subpopulations. The sample population analysed consisted of Spanish tourists with disabilities, with a sample size of 404 valid questionnaires and a confidence level of 95.5\%. Using the NSI (1999) and Eurostat (2005) data as the basis, four key elements for structuring the sample were established: gender (male / female), age (17-64 years of age / 65 and over), autonomous region (20 in total) and type of disability (physical, mental, sensory and hidden). 


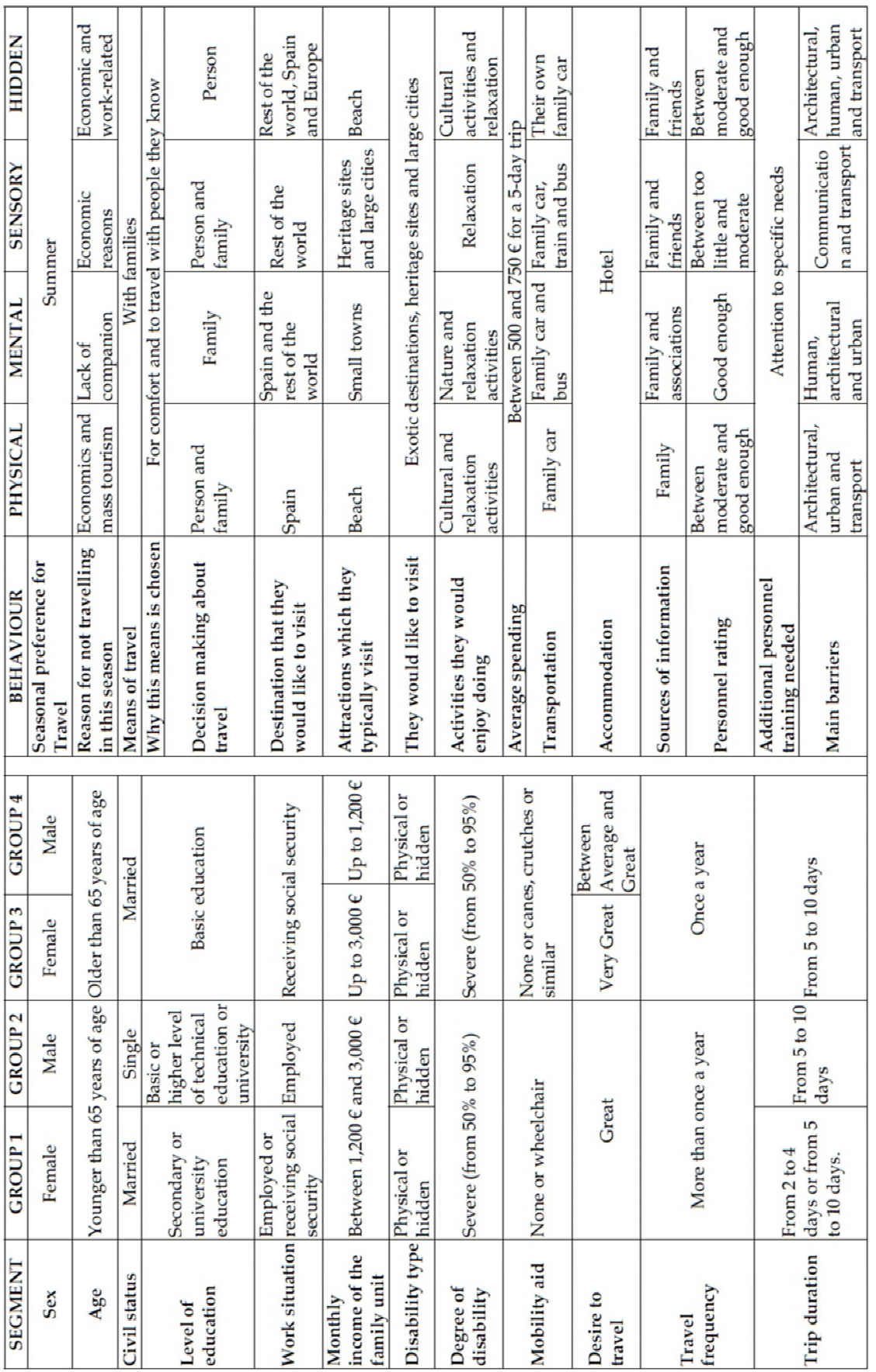

Table 5. Segmentation, behaviours and habits of tourists with disabilities 
Initially, the main customer segments were established according to their sociodemographic and economic characteristics. Subsequently, we studied the habits and behaviours of tourists with disabilities in Spain by type, as the needs of different groups are not always homogeneous (see Table 5). The results are synthesised in Table 5 and, due to the size of the data sample, exclude secondary and partially relevant aspects. The four groups identified in the table are the result of a cluster analysis that included the socio-demographic characteristics of the sample and travel-related variables.

The Spanish tourist with disabilities can be characterised as a user who generally chooses Spain as a destination, mainly looks to relax, travels with his/her family in the summer, stays at hotels and has an average expenditure of between $500 €$ and $750 €$ over 5 days. In addition, the segment of people younger than 65 years of age generally takes more than one trip per year given that they love to travel and have a monthly family income of between $1,200 €$ and 3,000 $€$. It is surprising that the group that travels the most comprises people with a severe degree of disability, i.e., those who have between $50 \%$ and $95 \%$ of their capabilities limited. It is important to highlight that the different disability groups all agree that the staff for the tourism sector should be better trained in order to attend to specific user needs. Last but not least, the study shows that architectural as well as human barriers are a constant, with the exception of the group with sensory disabilities, who highlighted communication and transportation barriers.

\subsection{The senior tourist}

One of the areas most relevant to the elderly is their leisure time, mainly their leisure time dedicated to tourism, which influences their physical, mental and social well-being (Lee and Tideswall, 2005; Vellas, 1986). In fact, it is possible to increase one's life expectancy and counteract the aging process by helping the person stay active. Travelling can also help people avoid loneliness and lack of meaning in the later stages of life, which are some of the main problems that older people have today (Marín, García-González and Troyano, 2006). Among the positive effects of leisure in the life of the elderly, Lee and Tideswell (2005) highlight life satisfaction. Travelling can be an enriching experience for senior citizens as it provides a change in their daily routine and the benefits of new experiences. Tourist activity involves movement / displacement to a different place from the place of residence, a form or manifestation of leisure, discovery, interaction with the environment, intercultural contact and social interaction. Santos (1992:36) found that older consumers spend more of their income on travel and less on other things.

As the tourist profile of the senior is not clearly established and there are several discussions about their socio-demographic characteristics, it was assumed that they are over 55 years of age, usually retired with pensions or social benefits, and have leisure time to devote to travelling at any time of the year. Delving a little deeper into their socio-demographic characteristics, we suggest that:

- With regards to sex, while it seems that, in maturity, women have a more dominant role than men with regards to purchasing decisions, especially after the retirement of the spouse (Gunter, 1998: 24). This behaviour cannot be generalised for all older women and ignores the changes that are occurring in the role of adult women today. 
- Marital status also does not determine the buying behaviour of senior citizens, and furthermore, different patterns in spending exist due to the changes in household structures produced in recent decades. Today, there are many statuses: married, single or widowed, as well as second marriages, and so on that will influence the patterns of consumption of senior citizens.

- Socioeconomic status, determined by educational level and occupation, can also differentiate various consumer groups. Gunter (1998:24) pointed out that those with a higher socioeconomic status are more receptive to brands and are also more influenced by the print media, as opposed to those with a lower socioeconomic status, who, as a result of increased consumption, are more influenced by television in their purchasing decisions. However, socioeconomic status alone does not ultimately determine the purchasing power and buying behaviour of the individual because, as seen above, these factors will also depend on other variables such as life cycle stage and individual biographies, which are constantly changing. Anken et al.(2008) and Grande (1993:100101) have argued that the purchasing behaviour of senior citizens is not determined exclusively by their age, gender, income or educational level, but that there are a number of variables related to the personality of the individual that are manifested in consumer lifestyles and are related to purchasing behaviour. Stroud (2008) has suggested that the psychographic variables used to segment this group are built on stereotypes of the elderly population and, in turn, Moschis (1992) calls into question the validity of these variables because, as is shown by some studies, the same lifestyles can apply to the whole population, young and old, regardless of the different lifestyles that depend on the characteristics of an older population (Moschis, 1993).

Accordingly, an interesting endeavour is to try to analyse the variables that allow for an understanding of the causes of why an older person travels or not, together with his or her needs, preferences and desires, which are key elements to discern to respond to their needs and enable them to access tourism. Variables such as the sources of information used, type of accommodation, number of people travelling, trip preparation time, travel duration, means of transport used and type of trip help to describe the behaviour of senior tourists, along with data on their motivations and socio-demographic characteristics.

\subsubsection{Motivations of senior tourists}

From a theoretical point of view, experts in the field of motivation have stated that motivation is involved in the reasons for our behaviour; an understanding of motivations is essential to understanding the decision-making process of travellers and fundamental to assessing their satisfaction with their tourism experiences (Pearce, 1982; Snepenger, King, Marshall and Uysal, 2006). The following table provides a brief description of the research that has been reviewed on the motivations of senior tourists and broader works in which the variables of motivation or reasons for travel were included in the study.

As can be observed, this market is not homogenous and different reasons can influence the choice of tourist activity. Senior citizens travel for many reasons, especially for: rest and relaxation, socialising, seeing new places and partaking in new experiences (Fleischer and Pizam, 2002). These reasons will depend on many factors including the person's sociocultural context, education and work environment. 


\begin{tabular}{|c|c|}
\hline $\begin{array}{c}\text { Authors and study } \\
\text { location }\end{array}$ & Senior citizen motivations \\
\hline $\begin{array}{l}\text { Horneman, Carter, Wey } \\
\text { and Ruys (2002) } \\
\text { Queensland (Australia) }\end{array}$ & $\begin{array}{l}\text { Travel while health is good } \\
\text { Spend time with family and friends } \\
\text { Visit places they have always wanted to visit } \\
\text { Make the most of free time }\end{array}$ \\
\hline $\begin{array}{l}\text { Acevedo (2003) } \\
\text { Brazil }\end{array}$ & $\begin{array}{l}\text { Try new things/visit new places } \\
\text { Rest and relax } \\
\text { Escape the daily routine } \\
\text { Interact with other people }\end{array}$ \\
\hline $\begin{array}{l}\text { Hossain, Bailey and } \\
\text { Lubulwa (2003) } \\
\text { Australia }\end{array}$ & $\begin{array}{l}\text { Vacations } \\
\text { Visit family }\end{array}$ \\
\hline $\begin{array}{l}\text { Huang and Tsai (2003) } \\
\text { Tapei and Kaohsiung } \\
\text { (Taiwan) }\end{array}$ & $\begin{array}{l}\text { The three most important: } \\
\text { Rest and relaxation } \\
\text { Meet people and socialise } \\
\text { Be with family }\end{array}$ \\
\hline $\begin{array}{l}\text { Lee and Tideswell (2005) } \\
\text { Korea }\end{array}$ & $\begin{array}{l}\text { Enjoy natural attractions } \\
\text { Visit new places and try new things } \\
\text { Rest and relaxation } \\
\text { Occupy free time }\end{array}$ \\
\hline $\begin{array}{l}\text { Chen (2009) } \\
\text { Tainan (Taiwan) }\end{array}$ & $\begin{array}{l}\text { There were no significant differences between the motivations } \\
\text { of both groups. } \\
\text { The two most important motivations are: } \\
\text { See things during vacations that they would not normally see } \\
\text { in their daily life } \\
\text { Be with family and friends }\end{array}$ \\
\hline
\end{tabular}

Table 6. Research on the motivations of senior citizen tourists

\subsubsection{Behaviour of the senior tourist}

The travel patterns and behaviours of senior citizens are very diverse, as was the case with their motivations. Thus, one can observe differences in their choices for food, accommodations, shopping and entertainment, among others (Bai et al., 2001:148).Those with the highest incidence are analysed below.

- Type of accommodation. Keep in mind that the type of accommodation used when travelling will be intrinsically linked to factors such as the reason for travel, income and company. In this regard, senior citizen tourists demonstrate a broad range of selection when choosing accommodations. 
- Travel Companions. Senior citizen tourists are very heterogeneous in this respect and this heterogeneity, as with the previous variable, arises from factors such as family circumstances, income and occupation.

- Travel time preparation. A better understanding of this behavioural variable, along with the source of information used by senior citizens when planning their trips, will be key to creating effective marketing to reach the target population efficiently and at the minimum cost. Some studies, for example, Gitelson and Crompton (1983), have stated that those who travel for longer periods of time and at greater distances plan further in advance. Conversely, those who visit family and friends plan less. Rao, Thomas and Javalgui (1992) found that those involved in more activities and who spend more have a longer planning horizon for their trips, and Fodness and Murray (1997 in Huh, 2006) have suggested that those who enjoy a longer stay, a greater number of destinations, visit more attractions and spend more dedicate more time to planning their trips.

- Duration of the trip. There is a wide disparity of opinions regarding this variable. However, it is commonly believed that senior tourists enjoy a longer stay than the rest of the population (VVAA in Batra, 2009:200). However, Bai et al. (1999:76) list the studies of several authors in this regard who note that the length of a senior citizen's trip can range from 1 to 3 nights, 4 to 5 nights or even up to 9 nights. Thus, there is no consensus on the typical duration of the senior citizen's trip, perhaps as a result of the homogeneity with which the collective of older travellers is treated by the tourism market and the lack of unified criteria when segmenting this group, as identified in the study by the authors.

- Means of transport. The car, in particular the private car, is the preferred mode of transportation by senior citizens for leisure travel, followed by planes and trains (Javalgi et al., 1992 in Patterson, 2006; Prideaux et al., 2001). However, it should also be noted that the bus is a very recurrent theme in this segment, highlighting its frequency of use as compared to the younger population (Baloglu and Shoemaker, 2001; VVAA in Patterson, 2006). The profile of the senior tourist that uses the bus as a means of transport is, according to Patterson (2006), typically a couple. However, Javalgi et al. (Patterson, 2006) have claimed that, after 65 years of age, the popularity of the car as the preferred mode of transportation by senior citizens decreases as age increases, with a tendency towards travel by bus, which is used more as the population ages. However, the means of transport is closely related to other factors related to tourism behaviours. In particular, the type of trip will determine the use of one type of transport or another. Moreover, this choice will also be influenced by the factors such as the reason for travel and the travel distance and destination (Patterson, 2006).

- Organisation of travel. Tour packages are one of the options preferred by the senior citizen versus the non-senior (Javalgi et al., in Bai et al., 2001), mainly for reasons of convenience, security and to have travel companions (Patterson, 2006). This is an alternative travel mode compared to travelling independently, especially for those senior citizens who are single, widowed or divorced (Patterson, 2006). There are many studies linking the package tour to people of advanced ages, using age as the sole criterion of segmentation (Bai et al., 1999). However, some of these studies (Bai et al., 2001; Javalgi et al., in Patterson 2006) have shown that age is only one of the variables that explain this behaviour and there are other variables such as sex, income, employment status, and type of companion. In this sense, Javalgi et al. (Patterson, 
2006:146) found relationships between the type of trip chosen and the traveller's employment status and income, among other factors; they suggested that retired senior citizens who depend on a retirement income prefer tour packages because these are cheaper, compared with senior citizens who are still active in the labour market and younger individuals. On the other hand, senior citizens also travel independently, especially younger ones who prefer to organise their trips themselves.

- Sources of information used. Varying sources of travel information are used. In several studies, there have been a number of interesting conclusions about the sources of information used by older people (Chen, 2009; Cleaver, 2000; Horneman et al., 2002; Grande, 1993; Shim et al., 2005):

- The main source of information for this group is their experience as consumers.

- The information search process is conditioned by the consumer's income, educational level and degree of socialisation.

- These consumers tend to collect information personally, which they then contrast with that provided by external media.

- Above all, they obtain information through family, friends, acquaintances, neighbours and word of mouth. Ananth, DeMicco, Moreo and Howey (1992) demonstrated that the comments concerning a hotel and its reputation play an important role in decision-making by older travellers when choosing a hotel.

- Older people also read a lot and listen to the radio. Therefore, the press and radio are very effective means to reach senior citizen tourists. Horneman et al. (2002) confirmed that the print media and travel agents were highly valued by this group, and Shim et al. (2005) highlighted the importance of mass media as a source of information.

- According to Grande (1993), the information that a company provides through its brochures or catalogues will not be widely read by older people. On the other hand, Ryan (1995) suggested that leaflets are the preferred media chosen by senior citizens and, according to this author, have a strong influence on the chosen destination.

\section{Sector Profitability - The cases of Europe and Spain}

When presenting figures for the potential profitability of the tourism sector associated with offering services to senior citizen tourists and visitors with disabilities, both in Europe and in Spain, it is important to reinforce the idea that this is not a niche offering, but rather expands current segments by differentiating based on accessibility and usability as quality parameters and, thus, increases satisfaction and loyalty among tourists.

As already mentioned, not all people with disabilities are able to travel, but according to Van Horn (2002), 70\% of Europeans with various accessibility needs are physically and financially able to travel and do so with an average of 0.5 companions per potential traveller. A fact that reinforces this statement is that of 4,000 respondents in the German study, $52 \%$ of the respondents travelled with a partner (German Federal Ministry of Economics and Technology, 2004). On average, 59\% of European households have a member with a disability and $38 \%$ of the population have a friend with a disability (Eurobarometer, 2001). On average, disabled people would take more than one vacation per year, travelling with more family members or friends, if they could find more and better information about accessible sites (Buhalis et al., 2005). 
If we combine all of the elements listed above, we can talk of a beneficiary market of more than 260 million disabled and older people that would generate tourism revenues of 166 billion euros (Eurostat, 2005), as can be seen more clearly in Table 7.

\begin{tabular}{|c|c|c|c|c|c|c|}
\hline $\begin{array}{c}\text { Overall } \\
\text { Demand }\end{array}$ & $\begin{array}{c}\text { T0\% are } \\
\text { physically } \\
\text { and } \\
\text { financially } \\
\text { able to } \\
\text { travel }\end{array}$ & $\begin{array}{c}\text { Multiplier } \\
\text { effect of } \\
\text { friends and } \\
\text { family }\end{array}$ & $\begin{array}{c}\text { Number } \\
\text { of } \\
\text { friends } \\
\text { and } \\
\text { family }\end{array}$ & $\begin{array}{c}\text { TOTAL } \\
\text { potential } \\
\text { market of } \\
\text { travellers }\end{array}$ & $\begin{array}{c}\text { Average } \\
\text { spending } \\
\text { per person } \\
\text { and per } \\
\text { vacation }\end{array}$ & $\begin{array}{c}\text { Potential } \\
\text { revenues } \\
\text { from } \\
\text { tourism }\end{array}$ \\
\hline $\begin{array}{c}127.5 \\
\text { million }\end{array}$ & 89.3 million & 0.5 & $\begin{array}{c}44.7 \\
\text { million }\end{array}$ & $\begin{array}{c}134 \\
\text { million }\end{array}$ & \multirow{2}{*}{$620 €$} & 83 billion $€$ \\
\cline { 3 - 5 } & 2 & $\begin{array}{c}178.6 \\
\text { million }\end{array}$ & $\begin{array}{c}267.9 \\
\text { million }\end{array}$ & 166 billon $€$ \\
\hline
\end{tabular}

Source: Eurostat, 2005.

Table 7. Potential market of European travellers that would benefit from increased accessibility and the associated tourism revenue.

The estimates presented above could be higher, mainly for two reasons. First, the calculations are based on the assumption that European citizens will take their holiday in Europe, but there are also tourists around the world who choose Europe as a holiday destination who have not been included. The estimate of potential travellers worldwide is between 600 and 900 million people. Second, the numbers cited refer only to people with disabilities or direct beneficiaries of accessibility while, as already mentioned, accessibility benefits all users (Buhalis et al., 2005).

Considering the facts presented above, the ignorance of the market towards the large group of disabled people seems incomprehensible. Nadine Vogel (2006) put forward three main reasons to explain this fact: people are generally uncomfortable with the disabled, the special needs of these groups are considered a "niche" and companies are afraid to "do it wrong".

Thus, the lack of accessibility of the tourism industry in relation to its goods, services and environments can result in three scenarios, (Franco, 1999):

- In general, accessibility is an element of quality and, if it is not available, the service offered is of lower quality.

- If the sector (industry, establishment, product, service or destination) does not consider this market segment and does not establish and meet accessibility standards, it will lose business opportunities from potential tourists with various disabilities (and their companions).

- Taking the opposite case, if they claim to be accessible and emphasise this competitive advantage, but really are not, they will take on costs of non-quality.

To identify the beneficiaries of accessibility and to identify the potential revenue for the tourism sector in Spain, we drew on the model designed by Eurostat (see Table 7) and the variable studied in the original model proposed by Eurostat, i.e., accessibility beneficiaries: the disabled, elderly, temporarily disabled and those with similar restricted capabilities. This effort was based on the data analysed in Table 3, the results from the quantitative study, that is, an initial demand of 15.7 million people who are beneficiaries of 
accessibility. By applying the multiplier effect of travel with 2 relatives or friends, we can calculate a potential demand of 32.97 million Spaniards out of a total population of 40.20 million people (according to the original study, i.e., NSI 1999). This is $82 \%$ of the population, to which would be added the percentage of people who do not travel; hence, the segment we consider in this scenario includes, directly and indirectly, nearly all of the Spanish population. Therefore, the potential revenue would range from nearly 8,000 million $€$ in the most negative case to 31,881 million $€$ in the most positive case.

\begin{tabular}{|c|c|c|c|c|c|c|c|}
\hline $\begin{array}{l}\text { Overall } \\
\text { Demand }\end{array}$ & $\begin{array}{c}70 \% \text { are } \\
\text { physically } \\
\text { and } \\
\text { financially } \\
\text { able to travel }\end{array}$ & \begin{tabular}{|c|} 
Multiplier \\
effect of \\
friends \\
and \\
family
\end{tabular} & $\begin{array}{l}\text { Number of } \\
\text { friends and } \\
\text { family }\end{array}$ & $\begin{array}{l}\text { TOTAL } \\
\text { potential } \\
\text { market of } \\
\text { travellers }\end{array}$ & \multicolumn{2}{|c|}{$\begin{array}{c}\text { Average } \\
\text { spending per } \\
\text { person and per } \\
\text { vacation }^{1}\end{array}$} & $\begin{array}{c}\text { Potential } \\
\text { revenues } \\
\text { from } \\
\text { tourism }\end{array}$ \\
\hline \multirow{4}{*}{$\begin{array}{c}15.7 \\
\text { million }\end{array}$} & \multirow{4}{*}{10.99 million } & \multirow{2}{*}{0.5} & \multirow{2}{*}{5.49 million } & \multirow{2}{*}{$\begin{array}{c}16.48 \\
\text { million }\end{array}$} & \multirow{4}{*}{$96.70 €$} & $\begin{array}{c}10 \\
\text { days }\end{array}$ & $\begin{array}{l}15,936.16 \\
\text { million } €\end{array}$ \\
\hline & & & & & & $\begin{array}{c}5 \\
\text { days }\end{array}$ & $\begin{array}{c}\text { 7,968.08 } \\
\text { million } €\end{array}$ \\
\hline & & \multirow{2}{*}{2} & \multirow{2}{*}{$\begin{array}{c}21.98 \\
\text { million }\end{array}$} & \multirow{2}{*}{$\begin{array}{l}32.97 \\
\text { million }\end{array}$} & & $\begin{array}{c}10 \\
\text { days }\end{array}$ & $\begin{array}{l}31,881.99 \\
\text { million } €\end{array}$ \\
\hline & & & & & & $\begin{array}{c}5 \\
\text { days }\end{array}$ & $\begin{array}{l}15,936.16 \\
\text { million } €\end{array}$ \\
\hline
\end{tabular}

Table 8. Scenario 2. Potential Spanish tourism market that benefits from increased accessibility and the associated tourism revenue

If the data discussed above are extrapolated to the entire tourism sector, the travel expenditure by the tourist resident in Spain, depending on the scenario chosen, would represent a range between $5.86 \%$ of total expenditure by Spanish tourists both nationally and internationally, when including only Spanish tourists with disabilities who travel with 0.5 companions once a year for an average duration of 5 days, up to an estimate of $97.32 \%$ of total expenditure by Spanish tourists, which includes all the potential beneficiaries of accessibility, travelling with an average of 2 relatives or friends and taking a trip with an average duration of 10 days each year.

\begin{tabular}{|c|c|c|c|}
\hline \multirow{2}{*}{$\begin{array}{c}\text { Scenario } \\
\mathbf{s}\end{array}$} & $\begin{array}{c}\text { Potential tourism } \\
\text { revenue from } \\
\text { beneficiaries of } \\
\text { accessibility }\end{array}$ & $\begin{array}{c}\text { Domestic and } \\
\text { international travel } \\
\text { expenditure by Spanish } \\
\text { residents (Familitur, } \\
\text { 2010) }\end{array}$ & $\begin{array}{c}\text { Percentage of potential } \\
\text { revenue compared to total } \\
\text { expenditure by Spanish } \\
\text { tourists }\end{array}$ \\
\hline \multirow{4}{*}{-} & $1,929.16$ million $€$ & & $5.86 \%$ \\
\cline { 2 - 2 } & $3,858.33$ million $€$ & & $11.77 \%$ \\
\cline { 2 - 2 } & $7,716.66$ million $€$ & \multirow{2}{*}{$32,757.28$ million $€$} & $23.55 \%$ \\
\cline { 2 - 2 } & $7,968.08$ million $€$ & & $24.32 \%$ \\
\cline { 2 - 2 }+ & $15,936.16$ million $€$ & & $48.64 \%$ \\
\cline { 2 - 2 } & $31,881.99$ million $€$ & & $97.32 \%$ \\
\hline
\end{tabular}

Table 9. Potential weight of the influence of accessibility on the entire Spanish tourist industry 
Both in the low (-) scenarios, as in the highest estimate, the estimated profitability is sufficient for public and private organisations to make an effort to seize the opportunity that is generated by expanding the tourism market and working on the basis of increases in quality and social responsibility.

\section{Conclusions}

At the beginning of this chapter, three clear objectives linked to senior tourism and accessible tourism were proposed: to determine the profile and behaviour of tourists from these segments, to identify the potential market opportunities and to estimate the economic revenues for Europe and Spain.

After carrying out this study, it can be concluded that in reference to the user profile and behaviour, there are groups with a range of superior needs who have a common characteristic, accessibility, who are considered to be any person able to use and enjoy products, tourist infrastructure and services. Focusing on the importance of the synergy between the two groups (elderly and disabled), one can establish that their demographic profiles are important but not decisive for the creation of tourism product offerings. Variables such as gender and age do not have a great influence on travellers' priorities, while educational level, occupation and status have a greater weight, as they are part of the lifestyle determinants of these segments. When we instead focus on behavioural elements, we reveal more accurate and determinate actions for establishing possible strategies to increase accessibility. It should be stressed that, for both segments, the main reasons for travel are searching for relaxation and rest, preferably using one's own vehicle (although this also depends on the destination of choice), with two main ranges of trip duration, not more than 3 or 4 days or 9 to 10 days. Accommodation choices are variable, but hotel stays are the most common, and word-of-mouth information is an important source of information for travel arrangements.

In terms of the market opportunities that exist and can be developed in the future, the potential of shifting tourism away from peak seasons is favoured, as most members of these groups do not perform paid work activities and receive some social benefits, which makes it possible for them to travel throughout the year, and they also have the purchasing power to do so. Moreover, in the case of Spain, this tendency is enhanced by the various state-run social programmes that co-finance holidays for the elderly or disabled. Non-seasonal tourism increases revenues and the use of infrastructure throughout the year, boosting destinations and, most importantly, creating jobs. It should be highlighted that these segments are not niche markets, but by expanding the market through improving products and services associated with accessibility, businesses increase their market potential and improve their image by increasing the quality and competitiveness of their tourism offerings.

Once we know how potential tourists who require accessibility behave and determine the opportunities that can be generated for different components of the tourism sector, both private and public, we still need to confirm whether this segment of tourism is attractive enough to make an effort to adapt and capture it through the supply of tourism goods and services. As has been noted, the potential market for elderly and disabled people varies according to the reference source, but if we summarise the data, we can estimate a target 
population of between 1.3 and 1.6 billion worldwide, 135 million in Europe and approximately 10 million in Spain. Understandably, not all of these people are able to travel, either because of health, economic or other limitations, but the data indicate that there is a potential European tourist revenue from beneficiaries of accessibility that varies between 83 and 166 billion $€$ depending on the number of companions. For the specific case of Spain, depending on the length of stay and the number of companions, the figure varies between 8,000 and 16,000 million $€$. Accessibility, directly and indirectly, benefits everyone, as can be observed by its potential influence on the entire Spanish tourist industry, for which the most positive scenario indicates that this segment of tourism could account for $97.3 \%$ of the potential revenue from travel expenditures made by Spanish tourists.

The appeal of attracting senior and disabled tourists in order to generate elements for new opportunities has been confirmed. Now, we wait for both the private and the public sectors to begin to develop their interest by increasing the supply of tourism products that meet accessibility parameters by and for all, i.e., increasing the quality of tourism offerings.

\section{Acknowledgment}

This research was made possible by funding from the Xunta de Galicia, project 09TUR005394PR.

\section{References}

Acevedo, C.R. (2003). Motivos para viajar: um estúdio com turistas maduros no contexto brasileiro. FACEP PESQUISA, Vol.6, No. 3, pp. 78-87, ISSN 1516-6503.

Alcaide, J. (2005). ¿Dónde está el Marketing para mayores? Marketing+Ventas, nº 205, sept., pp. 46-57, ISSN: 1130-8761.

Álvarez, C. (2006). Un ejemplo para Europa. Hosteltur. 04.05.2009, Available from: http://www.hosteltur.com.

Anken, A.K.; Chaipooopirutana, S. \& Combs, H. (2008). Psychographics and Patronage Behaviour of Mature Consumers in Thailand. International Review of Business Research Papers, Vol. 4, No 1, pp. 45-56, ISSN: 1832-9543.

Bai, B., Jang, S.S., Cai, L.A. \& O'Leary, J.T. (2001). Determinants of travel mode choice of senior travelers to the United States. Journal of Hospitality E Leisure Marketing, Vol. 8, No.3/4, pp.147-168, ISSN: 1541-0897.

Bai, B., Smith, W., Cai, L. \& O’LEary, J. (1999). Senior sensitive segments: Looking at travel behavior. In: K. S. Chon (Ed.), The Practice of Graduate Research in Hospitality and Tourism (pp. 75-89). ISBN: 0789007274, New York: The Haworth Hospitality Press.

Baloglu, S. \& Soemaker, S. (2001). Prediction of senior travelers' motorcoach use from demographic, psychological, and psychographic characteristics. Journal of Travel Research, Vol. 40, No.1, pp.12-18, ISSN: 1552-6763.

Barak, B. \& Schiffman L.G. (1981). Cognitive age: A nonchronological age variable. Advances in Consumer Research, Vol.8, pp.602-606, ISSN: 0098-9258.

Batra, A. (2009). Senior pleasure tourists: examination of their demography, travel experience, and travel behavior upon visiting the Bangkok metropolis. International Journal of Hospitality E Tourism Administration, Vol. 10, No. 3, pp. 197-212, ISSN: 1525-6499. 
Borja, L.; Casanovas, J.A. \& Bosch, A. (2002). El Consumidor turístico. ISBN: 8473562976, Pozuelo de Alarcón, Madrid: ESIC.

Brown, F. (1991). Tourism for all. Tourism Management, Vol.12, No. 3, pp. 258-260, ISSN: 02615177.

Buhalis, D., Eichhorn, V., Michopoulou, E. \& Millar, G. (2005). Accessibility market and stakeholder análisis. University of Surrey y One Stop Shop for Accesible Tourism in Europe (OSSATE).

Burnett, J.J. (1996). What services marketers need to know about the mobility-disabled consumer. The Journal of Services Marketing, Vol. $1^{\circ}$, No. 3, pp. 3-20, ISSN : 0887-6045.

Chen, H.W.J. (2009). Baby Boomers' and Seniors' Domestic Travel Motivations: An examination of citizens in Tainan, Taiwan. Master Thesis. University of Waterloo. Canada.

Cleaver, M. (2000). Australian seniors' use of travel information sources: perceived usefulness of word-of-mouth, professional advice, marketer-dominated and generalmedia information. ANZMAC 2000 Visionary Marketing for the 21 st Century, pp.1-6, ISBN 0 868579785.

European Commission (1996). Accesibilidad a Turistas con Discapacidad. Manual para la industria del turismo. DG XIII. Unidad “Turismo”, ISBN: 92-827-7298-5.

Community Research and Development Information Services (CORDIS) (1995). In: Cost 322: Low floor busses, 06.06.2007, Available from:

http:/ / www.cordis.lu/cost-transport/src/cost-322.htm

Darcy, S. (1998). Anxiety to Access: Tourism Patterns and Experiences of New South Wales People with a physical Disability. ISBN 0-7313-5500-8, Sydney, NSW: Tourism New South Wales.

Eurobarometer (2001). Attitudes of Europeans to Disability. In: Comisión Europea, 22.04.2007, Available from:

http://europa.eu.int/comm/public_opinion/archives/eb/ebs_149_en.pdf

Eurostat (2005). Employment of Disabled People in Europe 2002. Catálogo no KS-NP-05-013EN-N, Unión Europea. ISSN 1681-4789.

Eurostat (2003). Employment of Disabled People in Europe in 2002. Catálogo n: KS-NK-03026-EN-N, Unión Europea. ISSN 1024-4352.

German Federal Ministry of Economics and Technology (2004). Economic Impulses of Accesible Tourism for All. Berlín.

Fernández-Villarán, A. (2007). El acceso al turismo para las personas con discapacidad. Desafios y compromisos del turismo: hacia una visión más humana, Congreso UNIJES, Universidad de Deusto 2007, Bilbao, pp.47-59, ISBN: 978-84-9830-096-3.

Fleischer, A. \& Pizam, A. (2002). Tourism constraints among israelí seniors, Annals of Tourism Research, Vol. 29, No. 1, pp. 106-123, ISSN: 0160-7383.

Franco, P. (1999). La formación de los profesionales del turismo. Ocio y equiparación de oportunidades de las terceras jornadas de la Cátedra de Ocio y Minusvalías. Coord. Manuel Cuenca Cabeza, pp. 87-96, ISBN: 9788498309973.

Fuguet, T. (2008). Europa demanda más accesibilidad. Editur, Na 07, Jul, pp. 10-15, ISSN: 11346469.

García M.A. \& Martorell, O. (2007). Una reflexión sobre el modelo turístico de las Illes Balears. Decisiones basadas en el conocimiento y en el papel social de la empresa: XX Congreso anual 
AEDEM. Vol.1, pp. 1097-1106, ISBN 84-87600-43-3, Palma de Mallorca: AEDEM Ediciones.

Gerlin, A. (2005): Access Denied. Time Europe, Vol. 165, No.15. 30.03.2007, Available from: http://www.time.com/time/europe/magazine/article/0,13005,9010504111044655,00.html?promoid=rss_world

Gilson, S.F. \& Depoy, E. (2000). Multiculturalism and Disability: a critical perspectiva. Disability and Society, Vol. 15, No. 2, pp. 207-218, ISSN: 1360-0508.

Gitelson, R.J. \& Crompton, J.L. (1983). The Planning Horizons and Sources of Information Used by Pleasure Vacationers. Journal of Travel Research, January, Vol. 21, pp. 2-7, ISSN: 1552-6763.

González, A.M.; Rodríguez, C.; Miranda, M.R. \& Cervantes, M. (2009). Cognitive age as a criterion explaining senior tourists' motivations. International Journal of Culture, Tourism and Hospitality Research, Vol. 3, No. 2, pp.148-164, ISSN: 1750-6182.

Grande, I. (1993). El comportamiento de los consumidores por grupos de edad. Implicaciones sobre el diseño del mix de marketing. Distribución y Consumo. № 12, pp. 40-57, ISSN 1132-0176.

Gunter, B. (1998). Understanding the older consumer: the grey market. ISBN 9780415186445, Routledge. London.

Heumann, J.E. (1993). Bulding our own boats: a personal perspective on disability policy. Implementing the Americans with Disabilities Act: rights and responsibilities of all Americans. ISBN: 978-1557661197, O. Gostin \& H.A. Beyer Eds.

Horgan-Jones, M. \& Ringaert, L. (2004). Accessible Tourism in Manitoba. 04.03.2007, Available from :

http://www.ttra.com/pub/uploads/AccessibleTourismInManitoba.htm

Horneman, L. Carter, R.W., Wei, S. \& Ruys, H. (2002). Profiling the senior traveler: An Australian perspective. Journal of Travel Research, Vol. 41, No 1, pp. 23, ISSN: 15526763.

Hossain, A., Bailey, G. \& Lubulwa, M. (2003). Characteristics and Travel Patterns of Older Australians: Impact of Population Ageing on Tourism. International Conference on Population Ageing and Health: Modeling our Future. ISBN: 978-0444530059, Canberra, Australia.

Hsu, C.H.C. \& Lee, E.J. (2002). Segmentation of Senior Motor coach Travelers. Journal of Travel Research, Vol. 40, pp. 364-373, ISSN: 1552-6763.

Huang, L. \& Tsai, H-T. (2003). The study of senior traveler in Taiwan. Tourism Management, Vol. 24, pp. 561-574, ISSN: 02615177.

Huh, C. (2006). A study of changes in patterns of travel behavior over time: a cohort analysis approach. Tesis Doctoral. Michigan State University. United States.

Institute of Touristic Studies (IET) (2010). El turismo español en cifras, 2010. Informe Familitur. NIPO: 704-11-175-3.

Institute of Familiary Politic(IPF), (2009). Evolución de la familia europea, 2009.

Institute of Familiary Politic (2007). Evolución de la familia europea, 2007.

Institute of Familiary Politic (2006). Evolución de la familia europea, 2006. 
Iyer, R., Reisenwitz, T.H. \& Eastman, J.K. (2008). The impact of cognitive age on seniors'lifestyles. Journal of Marketing Managementl, Vol.18, No 2, fall, pp. 106-118, ISSN: 1472-1376.

Jang, S.C.S. y Wu, C.M.E. (2006). Senior's travel, motivation and the influential factors: An examination of Taiwanese senior. Tourism Management, Vol. 27, pp. 306-316, ISSN: 02615177.

Kim, J., Wei, S. y Ruys, H. (2003). Segmenting the market of West Australian senior tourist using an artificial neural network. Tourist Management, Vol. 24, pp. 25-34, ISSN: 02615177.

Lee, S.H. y Tideswell, C. (2005). Understanding attitudes towards leisure travel and the constraints faced by senior Koreans. Journal of Vacations Marketing, Vol. 11, No. 3, pp. 249-263, ISSN: 1479-1870.

Le Serre, D. (2008). Who is the senior consumer? Available from: http://www.marketingtrends-congress.com/2008_cp/Materiali/Paper/Fr/LeSerre.pdf

Leidner, R. (2006). Design for all in the economy: The example of tourism accessible for all in Europe. Newsletter Design For All Institute of India, Vol. 1 May 2006, No.4.

Littrell, M.A., Paige, R.C. \& Song, K. (2004). Senior travelers: Tourism activities and shopping behaviors. Journal of Vacation Marketing, Vol. 10, No. 4, pp. 348-362, ISSN: 1479-1870.

Marín, M., García - González, A.J. \& Troyano, Y. (2006). Modelo de ocio activo en las personas mayores: Revisión desde una perspectiva psicosocial. Revista Internacional de Ciencias Sociales y Humanidades, SOCIOTAM, Vol. 16, No 19, pp. 147-167, ISSN: 1405-3543.

Metz, D. \& Underwood, M. (2005). Older, richer, fitter: identifying the consumer needs of Britain's ageing population. ISBN: 978-0862423834, Age Concern England. London.

Ministry of Labour and Social Affairs (2003). I Plan Nacional de Accesibilidad 2004-20012. Por un nuevo paradigma, el Diseño para Todos, hacia la plena igualdad de oportunidades.

Ministry of Labour and Social Affairs (2003). Libro Blanco de Accesibilidad. Por un nuevo paradigma, el Diseño para Todos, hacia la plena igualdad de oportunidades.

Ministry of Labour and Social Affairs (2002). Libro verde. La accesibilidad en España. Diagnóstico y bases para un plan integral de superación de barreras.

Moschis, G.P. (1993). “Gerontographics: a scientific approach to analyzing and targeting the mature market" Journal of Consumer Marketing, Vol. 10, n 3, pp. 43-53, ISSN: 07363761.

Moschis, G.P. (1992). Marketing to older consumers: a handbook of information for strategy development. ISBN: 978-0899307640, Quorum Books. Westport.

National Agency for New Technologies, Energy and Environment of Italy (ENEA) (1999). Tourism Services for Accessibility and a Comfortable Stay.

National Disability Authority (2003). Accessibility and Tourism. In: Tourism Policy Review Group, 26.02.2007, Available from: http://www.nda.ie/

National Institute of Statistics (INE), (2008). Encuesta sobre Discapacidad, Deficiencia y Estado de la Salud -EDDES-, 2008.

National Institute of Statistics (1999). Encuesta sobre Discapacidad, Deficiencia y Estado de la Salud -EDDES-, 1999.

National Institute of Statistics (1999a). Encuesta de Población Activa (EPA), 1999. 
National Institute of Statistics (1997. Encuesta de Movilidad Hospitalaria (EMH), 1997.

Nedelea, A. y State, M. (2008). The demographic ageing and consumer market. Ştiințe Economice, Tom. XVII, Volumul IV- Management and Marketing, pp. 1010-1014. Universitatea din Oradea. Romania. Available from: http://steconomice.uoradea.ro/anale/volume/2008/v4-managementmarketing/v4- management-and-marketing.pd

Norman, W.C., Daniels, M.J., McGuire, F. \& Norman, C.A. (2001). Wither the mature market: An empirical examination of the travel motivations of neo-mature and veteranmature markets. Journal of Hospitality $\mathcal{E}$ Leisure Maketing, Vol. 8 No 3/4, pp.113-130, ISSN: 1541-0897.

Patterson, I. (2006). Growing older. Tourism and leisure behaviour of older adults. ISBN: 9781845930653, Cambridge. Ed. Cabi.

Pearce, P.L. (1982). The Social Psychology of Tourist Behavior. ISBN: 978-0080257945, Oxford: Pergamon.

Pérez, M.D. \& González, D.J. (2003). Turismo Accesible: Hacia un turismo para todos. In: MAZARS, Available from: http://cermi.es/documentos/descargar/Turismoaccesible/ta.pdf.

Prideaux, B.; Wei, S. \& Ruys, H. (2001). The senior drive tour market in Australia. Journal of Vacation Marketing. Vol. 7, No 3, pp. 209-219, ISSN: 1479-1870.

Pühretmair, F. (2004). It's time to make eTourism accesible. In Miesenberger, K., Klaus, J., Zagler, W. y Burger, D. (Eds.) Computers helping people with special needs. 9th Internacional Conference, ICCHP 2004, ISBN : 978-3-540-70539-0, France y Berlín.

Qualitas (2004). Conclusions of the 1st International Congress on "Tourism for all”. In: WTO, 25.04.2007, Available from:

http://www.worldtourism.org/quality/E/standards2.htm

Rains, R. (2008): 2000 Bali Declaration on Barrier-Free Tourism for people with Disabilities. In: Report Asia-Pacific Conference on Tourism for People with Disabilities. 01.04.2008, Available from:: http://www.rollingrains.com/archives/002167.html

Rao, S.R., Thomas, E.G., y Javalgui, R.G. (1992). Activity preferences and trip planning behavior of the U.S. outbound pleasure travel market. Journal of Travel Research, 30(3):3-12.

Reece, W.S. (2004). Are Senior Leisure Travelers Different? Journal of Travel Research, Vol. 43, No 1, pp. 11-18, ISSN: 1552-6763.

Ryan, Chris (1995). Learning about tourists from conversations: the over-55s in Majorca. Tourism Management, Vol. 16, No 3, pp. 207-215, ISSN: 02615177.

Salgado, S. (2007). Editorial Polibea", Turismo@Polibea, Febrero de 2007, No34. In: Polibea, 15.01.2008, Available from: www.polibea.com

Santos, J.L. (1992). Las nuevas tendencias de los consumidores turistas. Estudios sobre consumo, No 23, pp. 33-43, ISSN: 0212-9469.

Sellick, M.C. (2004). Discovery, Connection, Nostalgia: Key Travel Motives within the Senior Market. Journal of Travel ETourism Marketing, Vol. 17, nNo 1, pp. 55-71, ISSN: 15407306. 
Shim, S., Gehrt, K.C. \& Siek, M. (2005). Attitude and Behavior Regarding Pleasure Travel among Mature Consumers: A Socialization Perspective. Journal of Travel $\mathcal{E}$ Tourism Marketing, Vol. 18, No 2, pp. 69-81, ISSN: 1540-7306.

Snepenger, D., King, J., Marshall, E. \& Uysal, M. (2006). Modeling Iso-Ahola's Motivation Theory in the Tourism Context. Journal of Travel Research, No 45, pp. 140-149, ISSN: 1552-6763.

Stroud, D. (2008). The 50 plus market: why the future is age neutral when it comes to marketing $\mathcal{E}$ branding strategies. ISBN: 978- 0749449391, Kogan Page. London.

Stumbo, N.J. \& Pegg, S. (2005). Travellers and Tourists with Disabilities: A Matter of Priorities and Royalties. Tourism Review Internacional, Vol. 8, No3, pp. 195-209, ISSN: 1544-2721.

Toerisme V. (2001). Tourism for all in the European Union. Status Report on Tourist Accommodation Schemes in Europe. Meeting of EU Ministers of Tourism, "Tourism for all", 2001. 13.03.2007, Available from:

http:/ /www.toegankelijkheidsbureau.be/docs/Tourism\%20for\%20All\%20Report $\% 2$ OFinal\%20SEP2001b.pdf

Tongren, H.N. (1988). Determinant Behavior Characteristics of Older Consumers. The Journal of Consumer Affairs, Vol.22, No1, ISSN: 1745-6606.

U.S. Department of Commerce (1997). Current Population Report: Americanswith Disabilities: 1994-95. In: US Goverment, 05.04.2007, Availabe from:

http://census.gov.hhes/www/disable/sipp/disable9495

Van Horn, L. (2002).Travellers with Disabilities: Market Size and Trenes. 03.05.2007, Available from: http://ncpedp.org/access/isu-travel.htm

Vellas, P. (1986). Aspectos psicológicos y sociales del desarrollo del turismo en la tercera edad. Primeras Jornadas Técnicas de Turismo y Tercera Edad, Alicante.

Vogel, N. (2006). Not Marketing to People with Disabilities? You're Missing Out. Most Marketers are Ignoring Loyal Consumer Segment That has 'Sizable Spending Power". In: Consults Pring Board, 30.09.2008, Available from:

http://www.consultspringboard.com/pdf/AdvertisingAgeArticle-Published.pdf

Wang, K. C. (2006). Motivations for Senior Groups Package Tour Tourists. Journal of Tourism Studies, Vol. 12, No. 2, pp. 119-138, ISSN: 1035-4662.

Wilkes, R. E. (1992). A structural modeling approach to the measurement and meaning of cognitive age. Journal of Consumer Research, Vol.19, pp.292-301, ISSN: 0093-5301.

World Health Organization (WHO) (2001). Clasificación Internacional del Funcionamiento, de la Discapacidad y de la Salud (CIDDM-2).

World Tourism Organization (WTO) (2001). Tourism 2020 Vision. Europe. Vol. 4. ISBN: 9789284403806, UNWTO.

World Tourism Organization (1980). Declaración Mundial de Manila sobre el Turismo Mundial", del 23 de septiembre de 1980, aprobada por la Confederación Mundial de Turismo.

Zimmer, Z., Braley, R.E. \& Searle, M.S. (1995). Weather to go and where to go: identification of important influences on senior's decisions to travel. Journal of Travel Research, Vol. 33, pp. 3-10, ISSN: 1552-6763. 


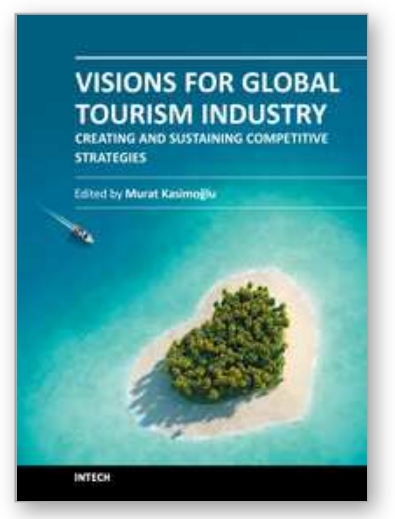

\section{Visions for Global Tourism Industry - Creating and Sustaining Competitive Strategies}

Edited by Dr. Murat Kasimoglu

ISBN 978-953-51-0520-6

Hard cover, 478 pages

Publisher InTech

Published online 18, April, 2012

Published in print edition April, 2012

We have been witnessing huge competition among the organisations in the business world. Companies, NGO's and governments are looking for innovative ways to compete in the global tourism market. In the classical literature of business the main purpose is to make a profit. However, if purpose only focus on the profit it will not to be easy for them to achieve. Nowadays, it is more important for organisations to discover how to create a strong strategy in order to be more competitive in the marketplace. Increasingly, organisations have been using innovative approaches to strengthen their position. Innovative working enables organisations to make their position much more competitive and being much more value-orientated in the global tourism industry. In this book, we are pleased to present many papers from all over the world that discuss the impact of tourism business strategies from innovative perspectives. This book also will help practitioners and academician to extend their vision in the light of scientific approaches.

\section{How to reference}

In order to correctly reference this scholarly work, feel free to copy and paste the following:

Elisa Alén, Trinidad Domínguez and Nieves Losada (2012). New Opportunities for the Tourism Market: Senior Tourism and Accessible Tourism, Visions for Global Tourism Industry - Creating and Sustaining Competitive Strategies, Dr. Murat Kasimoglu (Ed.), ISBN: 978-953-51-0520-6, InTech, Available from:

http://www.intechopen.com/books/visions-for-global-tourism-industry-creating-and-sustaining-competitivestrategies/new-opportunities-for-the-tourism-market-senior-tourism-and-accessible-tourism

\section{INTECH}

open science | open minds

\section{InTech Europe}

University Campus STeP Ri

Slavka Krautzeka 83/A

51000 Rijeka, Croatia

Phone: +385 (51) 770447

Fax: +385 (51) 686166

www.intechopen.com

\section{InTech China}

Unit 405, Office Block, Hotel Equatorial Shanghai

No.65, Yan An Road (West), Shanghai, 200040, China

中国上海市延安西路65号上海国际贵都大饭店办公楼 405 单元

Phone: +86-21-62489820

Fax: $+86-21-62489821$ 
(C) 2012 The Author(s). Licensee IntechOpen. This is an open access article distributed under the terms of the Creative Commons Attribution 3.0 License, which permits unrestricted use, distribution, and reproduction in any medium, provided the original work is properly cited. 